\title{
MODELING OF HYDRODYNAMIC AND HEAT AND MASS TRANSFER PROCESSES IN ABSORPTION OF THE DRYING AIR EMISSIONS
}

\author{
Shchedrina Galina Gennadevna*, Shchedrin Dmitrii Gennadevich \\ Southwest State University, Kursk, Russia
}

High efficiency drying wet gases are film contact apparatus chlorotoluene installations. The object of the study is ventilation emissions characterized by high moisture content. The paper presents a mathematical model of the absorption drying of wet ventilation emissions for devices with a regular nozzle of rigidly fixed porous plates of microporous plastic. The obtained criterion equations allow to carry out engineering calculations of air drying absorption devices.

Key words: contact film-type apparatus, lithium chloride, ventilation emissions, absorption, microporous plastic, hydrodynamic processes, heat and mass transfer processes, criterion equations

\section{INTRODUCTION}

Sorbents are often used to absorb water vapor from the dried air. Reduction of moisture content in this case can be carried out in the process of adsorption, absorption or chemical sorption $[1,2,3]$.

High efficiency of wet gas drying is achieved by contact film devices of chloride-lithium plants [4] due to the possibility of operation at high air mass velocity and low aerodynamic resistance.

Air drying is mainly produced using adsorption and absorption processes. These phenomena are purely physical in nature, because there is no chemical reaction of the compound of the absorbing material with water vapor. As scavengers adsorption using activated carbon, silica gel, etc., and upon absorption of aqueous salt solutions (lithium chloride, calcium chloride, etc.). The most relevant for the study are ventilation emissions from the devices of the "wet group", characterized by increased moisture content (concentrators, dryers, etc.), as well as emissions of General ventilation from the upper zone of the shops with a temperature in the cold period of the year $15-20^{\circ} \mathrm{C}$ and relative humidity up to $50 \%$.

Since industrial ventilation emissions contain harmful substances, in order to protect the atmosphere, they are mainly directed to combustion in catalytic afterburners. As a result of transportation of such air to incineration plants without preliminary decrease in moisture content there is a fast failure of the expensive equipment. Do not stand up to their normative service life of heat exchangers, catalyst, fans, and piping due to corrosion of the metal. Therefore, in order to ensure normal operation and increase the service life of the listed equipment, it is necessary to carry out effective drying of ventilation emissions of this category.

\section{PROPOSED ENGINEERING SOLUTIONS}

Dehydration port (absorption apparatus) differ in the way the absorbent is supplied. A number of authors [5, 6, 13, 14] carried out a comparison of different types of absorption devices for a number of regime parameters, which showed that the film contact heat and mass exchanger, having the highest energy index, has the best characteristics for the entrainment, which is especially important when working on a solution of lithium chloride, the cost of which is higher than the cost of water. Less risk of breakdown and entrainment of drops of lithium chloride solution is one of the most significant advantages of filmtype dehumidification chambers.

On the laboratory bench (Fig. 1) investigated the operation of the apparatus with surfaces made of plates of sheet microporous plastic, which is a microporous polychlorinated, obtained by sintering [7].

During the experiments, the air velocity varied within $1 \div 6 \mathrm{~m} / \mathrm{s}$, the irrigation density $-50 \div 120 \mathrm{~kg} / \mathrm{m}^{2} \times \mathrm{h}$. In all experiments, the size of the microporous plastic plates remained constant and was $0.3 \times 0.4 \mathrm{~m}[8,9]$.

The air temperature at the entrance to the drying chamber on a dry thermometer varied from $18^{\circ} \mathrm{C}$ to $45^{\circ} \mathrm{C}$, the temperature of the wet thermometer, respectively, varied from $11^{\circ} \mathrm{C}$ to $32^{\circ} \mathrm{C}$. During the experiments, the initial temperature of the absorbent varied from $20^{\circ} \mathrm{C}$ to $50^{\circ} \mathrm{C}$, the initial concentration of the absorbent during the experiments was constant and was $40 \%$.

The air in the experimental setup was supplied by a fan 1 to the air preparation part, which consists of an electric heater 2, an air cooler 3 and a humidifier 4 . Further, the air with the specified parameters was supplied to the air drying apparatus. The main element of which is the surface 5 (Fig. 2) size $0.3 \times 0.4 \mathrm{~m}$, made of microporous plastic, which has a porous structure and is impregnated with a solution of lithium chloride, forming a thin film of 
absorbent, which does not create entrainment of droplets at significant air flow rates. The walls of the air drying unit are made of transparent material (silicate glass), which allows to visually monitor the flow hydrodynamics. Wet air, in contact with the absorbent film, is drained and enters the filter 6 , where the absorbent droplets are captured. The temperature and humidity of the air before and after drying are measured by dry 7 and wet 8 thermometers. The average air flow rate is measured using anemometer 9 .

Air flow is regulated by a flap 12. The absorbent ( $\mathrm{LiCl})$ from the tank 13 is supplied by the pump 14 to the upper chamber of the air drying apparatus, in which the set level is maintained by the valve 16 .

The temperature of the absorbent before and after drying is measured by thermometers 18,19 . The consumption of absorbent is measured by the gravimetric meth- od. Initial and final moisture content of the absorbent is measured by measuring the density by the gravimetric method, samples are collected from the samplers 20, 21. The moistened absorbent from the lower chamber of the drying apparatus 22 is discharged through the trap 23, into the container 24.

Desorption was performed by evaporation of the selected absorbent [10].

Dynamics of change of entrainment with increasing speed above the critical was recorded by the amount of solution and determined by the balance equation:

$W=G_{2}-G_{1}-G_{\mathrm{y}}$

$\mathrm{W}$ - amount of adsorbed moisture, $\mathrm{kg} / \mathrm{h}$;

$\mathrm{G}_{2}$ - quantity of solution leaving the apparatus, $\mathrm{kg} / \mathrm{h}$;

$\mathrm{G}_{1}$ - quantity of solution entering the apparatus, $\mathrm{kg} / \mathrm{h}$;

$\mathrm{G}_{\mathrm{y}}$ - amount of solution carried away by the flow, $\mathrm{kg} / \mathrm{h}$.

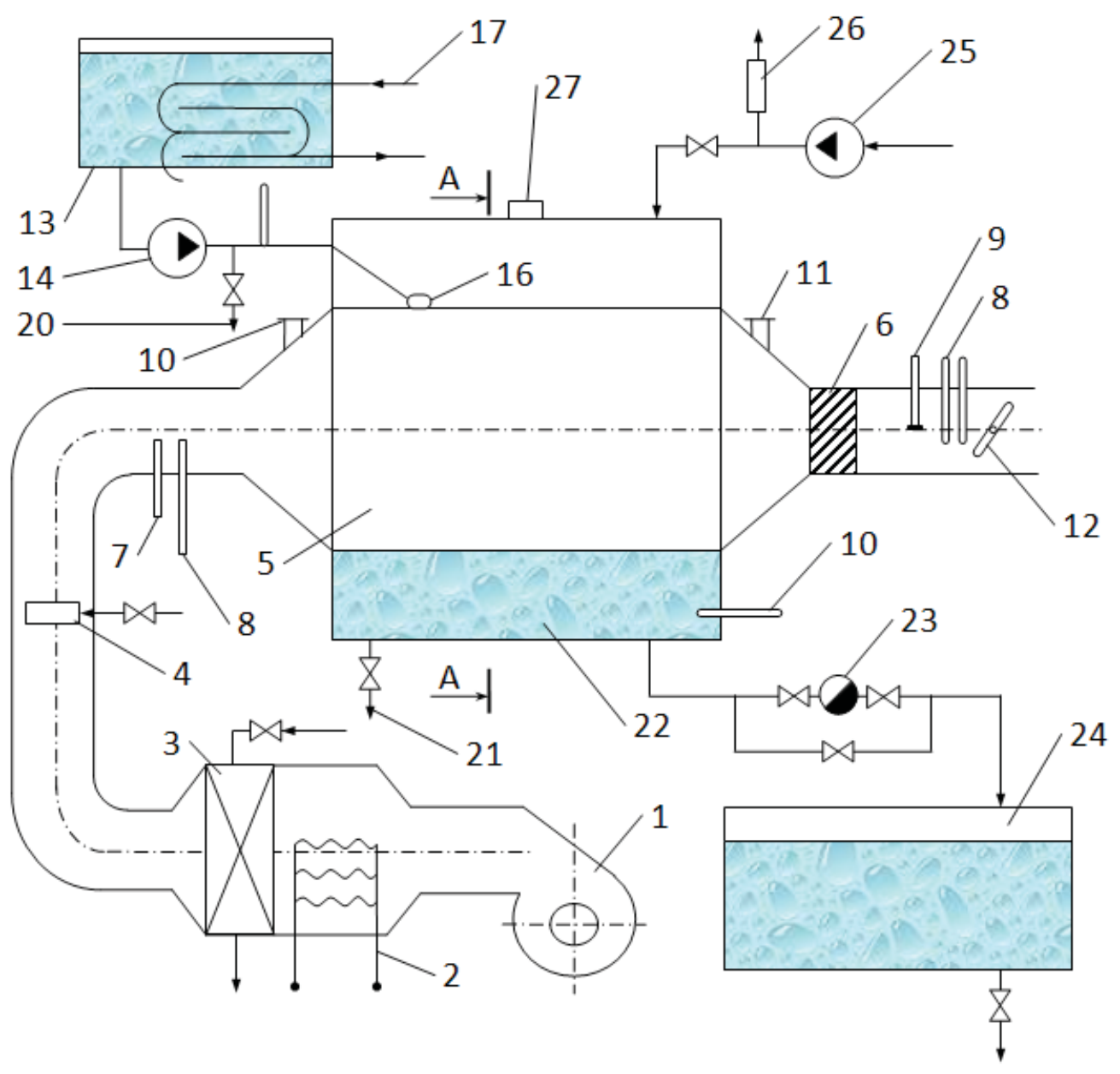

Figure 1: - schematic diagram of the experimental stand

1 - air mover; 2 - electric heater; 3 - air cooler; 4 - humidification device; 5 - porous plates of microporous plastic; 6 - filter; 7 - dry thermometer; 8 - wet thermometer; 9 - anemometer; 10 - branch pipe; 11 - branch pipe; 12 - damper; 13 - capacity with absorbent; 14 - pump; 16 - valve; 17-coil; 18 - thermometer; 20, 21 - samplers; 23 - condensate trap; 24 - capacity for receiving absorbent; 25 - blower pump; 26 - control valve; 27 - branch pipe for micropressure gage. 
Readings were taken and sampling of the solution was carried out under steady-state conditions.

The hydrodynamic regime during the experiments changed due to changes in air flow and the area of the living section of the drying chamber. The live section of the drying chamber was changed by changing the distance between the miplast plates from 10 to $30 \mathrm{~mm}$.

Two factors were of great importance for the operation of the drying chamber: the air speed and the degree of irrigation (Fig.1). At low air velocities (1-2 m/s) laminar regime was observed and there was no entrainment of the absorbent in the form of droplets at all ranges of irrigation of porous plates. With a further increase in air $(3 \mathrm{~m} / \mathrm{s})$, there was an increase in the entrainment of the absorbent in the form of drops, especially this process progressed with an increase in the degree of irrigation.

Obviously, the reduction of channels due to the increase in the irrigation film, as well as the formation of droplets in the air flow do not have a significant effect on the aerodynamic resistance.

\section{THE RESULTS OF MATHEMATICAL MODELING OF HYDRODYNAMIC AND HEAT AND MASS TRANSFER PROCESSES}

The hydrodynamics of the process in the drying chamber is described by the Navier-Stokes differential equation for a continuum moving along the $Z$ axis (i.e. along the drying chamber).

$$
\begin{aligned}
& \rho\left(\frac{\partial \omega_{z}}{\partial \tau}+\omega_{x} \frac{\partial \omega_{z}}{\partial x}+\omega_{y} \frac{\partial \omega_{z}}{\partial z}\right)= \\
& =-\rho g-\frac{\partial p}{\partial z}+\mu\left(\frac{\partial^{2} \omega_{z}}{\partial x^{2}}+\frac{\partial^{2} \omega_{z}}{\partial y^{2}}+\frac{\partial^{2} \omega_{z}}{\partial z^{2}}\right)
\end{aligned}
$$

$\rho$ - density of drying agent,

$\omega_{z}$ - the speed of the drying agent along the $Z$ axis;

$T$ - time;

$x, y, z$ - coordinate system;

$g-$ acceleration of gravity;

$p$ - pressure,

$\mu$ - viscosity of the drying agent.

In this work, the steady-state mode of motion of the

drying agent was considered, therefore $\frac{\partial \omega^{2}}{\partial \tau}=0$

Analysis and transformation of the equation (3.2) by methods of similarity theory allow to obtain a General form of criterion equations that contain constant coefficients [11].

For laminar flow:

$$
\begin{aligned}
& \Delta P=A(\rho \omega)^{a 1} \theta^{b 1}\left(\frac{H}{d_{\vartheta}}\right)^{c 1} \\
& E_{u}=B \cdot \operatorname{Re}^{e 1}\left(\frac{H}{d_{\vartheta}}\right)^{q 1}
\end{aligned}
$$

$$
\begin{aligned}
& \text { for the turbulent regime: } \\
& \Delta P=D(\rho \omega)^{a 2} \theta^{b 2}\left(\frac{H}{d \ni}\right)^{c 2} \\
& E_{U}=E \cdot \operatorname{Re}_{b}{ }^{e 2} \cdot \operatorname{Re}_{a}{ }^{e 3}\left(\frac{H}{d \ni}\right)^{q 2}
\end{aligned}
$$

Thermal processes in the drying chamber describes the differential equation of convective heat transfer (Fourier-Kirchhoff equation).

$$
\begin{aligned}
& \frac{\partial t}{\partial \tau}+\frac{\partial t}{\partial x} \cdot \omega_{x}+\frac{\partial t}{\partial y} \cdot \omega_{y}+\frac{\partial t}{\partial z} \cdot \omega_{z}= \\
& =a \cdot\left(\frac{\partial^{2} t}{\partial x^{2}}+\frac{\partial^{2} t}{\partial y^{2}}+\frac{\partial^{2} t}{\partial z^{2}}\right) \\
& t \text { - temperature, } \\
& T \text { - time, }
\end{aligned}
$$

$\omega_{x^{\prime}} \omega_{y^{\prime}} \omega_{z}-$ the projection of the velocity on the axis of $a=\frac{\lambda}{c \rho}$ - thermal diffusivity;

$\lambda$ - thermal conductivit;

$c$ - thermal capacitance;

$\rho$ - density.

The transformation of the Fourier-Kirchhoff differential equation allows us to obtain a General criterion equation that describes the thermal processes in the drying chamber:

$N u=F \operatorname{Re}^{f 1} \cdot \operatorname{Pr}^{f 2} \cdot\left(\frac{H}{d_{3}}\right)^{f 3}$

$\mathrm{F}, f_{1}, f_{2}, f_{3}-$ constant coefficients, which are determined experimentally;

$\mathrm{Re}$ - the Reynolds criterion;

$\mathrm{Pr}$ - the Prandtl number of the heat exchange;

$\mathrm{Nu}$ - the criterion Nusselt heat exchanger.

Mass transfer processes in the drying chamber are described by the differential equation of convective mass transfer:

$$
\begin{aligned}
& \frac{\partial c}{\partial x} \cdot \omega_{x}+\frac{\partial c}{\partial y} \cdot \omega_{y}+\frac{\partial c}{\partial z} \cdot \omega_{z}= \\
& =D\left(\frac{\partial^{2} c}{\partial x^{2}}+\frac{\partial^{2} c}{\partial y^{2}}+\frac{\partial^{2} c}{\partial z^{2}}\right)
\end{aligned}
$$

or:

$\omega \cdot \operatorname{grad} C=D \nabla^{2} C$

$C$ - the concentration of the component; $D$ - molecular diffusion coefficient.

(3) General criterion equation describing mass transfer in the drying chamber:

$N u_{D}=Y \cdot \operatorname{Re}_{B}^{\gamma 1} \cdot \operatorname{Pr}_{D}^{\gamma 2} \cdot\left(\frac{H}{d_{\ni}}\right)^{\gamma 3}$ 
$\mathrm{Nu} u_{D}$ - the criterion Nusselt diffusion;

$\mathrm{Re}_{B}$ - Reynolds criterion for air;

$\operatorname{Pr}_{D}$ - Prandtl's diffusion criterion;

$\mathrm{Y}, \mathrm{Y}_{1}, \mathrm{Y}_{2}, \mathrm{Y}_{3}$ - constant coefficients, which are determined by experimental data.

As a result of processing the experimental data by the least squares method, constant coefficients for the criterion equations were determined [12].

The hydrodynamic regime in the drying chamber will be described by the following specific criterion equations: for laminar flow:

$$
\begin{aligned}
& \Delta P=2,18 \cdot 10^{-1} \cdot(\rho \omega)^{1,96} \cdot \Theta^{0,15} \cdot\left(\frac{H}{d_{\dot{y}}}\right)^{0,86} \\
& E u=5,11 \cdot \operatorname{Re}_{b}^{-0,52} \cdot \operatorname{Re}_{\grave{a}}^{0,28} \cdot\left(\frac{H}{d_{\dot{y}}}\right)^{0,76}
\end{aligned}
$$

for the turbulent regime:

$$
\begin{aligned}
& \Delta P=1,88 \cdot 10^{-3} \cdot(\rho \omega)^{3,15} \cdot \Theta^{0,43} \cdot\left(\frac{H}{d_{\dot{y}}}\right)^{2,66} \\
& E u=6,17 \cdot 10^{-5} \cdot \operatorname{Re}_{b}^{5,19} \cdot \operatorname{Re}_{\grave{a}}^{0,56} \cdot\left(\frac{H}{d_{\dot{y}}}\right)^{2,03}
\end{aligned}
$$

Heat and mass transfer processes in the drying chamber will be described by the following criteria equations:

$$
\begin{aligned}
& \frac{\Delta I}{I}=1,98 \cdot 10^{-3} \cdot \operatorname{Re}_{b}^{0,52} \cdot\left(\frac{H}{d_{\dot{y}}}\right)^{0,21} \cdot\left(\frac{t_{\hat{\mathrm{a}}}}{t_{\mathrm{à}}}\right)^{1,17} \cdot\left(\frac{x_{\mathrm{a}}}{x_{\mathrm{a}}}\right)^{0,12} \\
& \Delta X=6,7 \cdot 10^{-3} \cdot \operatorname{Re}_{b}^{0,29} \cdot\left(\frac{H}{d_{\dot{y}}}\right)^{0,09} \cdot\left(\frac{t_{\mathrm{a}}}{t_{\mathrm{a}}}\right)^{0,59} \cdot\left(\frac{x_{\hat{\mathrm{a}}}}{x_{\mathrm{a}}}\right)^{1,31} \\
& N u=1,44 \cdot 10^{-3} \cdot \operatorname{Re}^{1,82} \cdot \operatorname{Pr}^{0,16} \cdot\left(\frac{H}{d_{\dot{y}}}\right)^{-0,50} \\
& N u_{g}=0,79 \cdot \operatorname{Re}_{b}^{1,77} \cdot \operatorname{Pr}^{0,11} \cdot\left(\frac{H}{d_{\dot{y}}}\right)^{-0,85}
\end{aligned}
$$

It should be noted that the equations obtained are valid for the system of humid air $-40 \%$ lithium chloride.

The resulting equations (12) - (19) allow us to determine the aerodynamic resistance of the drying chamber at different channels and degrees of irrigation, the coefficient of heat transfer and coefficient of mass transfer, which gives the opportunity to carry out engineering calculations of the absorption apparatus, the drying air with a high moisture content.

\section{CONCLUSION}

A mathematical model of absorption drying of wet ventilation emissions for devices with a regular nozzle of rigidly fixed porous plates is developed. It should be noted that the obtained criterion equations are valid for the system of humid air $-40 \%$ lithium chloride. The resulting equations (12) - (19) allow us to determine the aerodynamic resistance of the drying chamber at different channels and degrees of irrigation, the coefficient of heat transfer and coefficient of mass transfer, which gives the opportunity to carry out engineering calculations of the absorption apparatus, the drying air with a high moisture content.

\section{REFERENCES}

1. Gogish L.V., Stepanov G.Yu. Gidrodinamicheskie modeli turbulentnogo otryvnogo obtekaniya tel// Strujnye i otryvnye techeniya / Sb. nauchn. tr.(in-t mekhaniki MGU). - M., 1989. - S.39-49.

2. Kutateladze S.S., Leont'ev A.M. Teplomassoobmen i trenie $v$ turbulentnom pogranichnom sloe. - M.: Energoatomizdat, 1985. - $320 \mathrm{~s}$.

3. Kejs V.M. Konvektivnyj teplo- i massoobmen. - M.: Energiya, 1972. - $440 \mathrm{~s}$.

4. Birkgof G. Gidrodinamika [Tekst] :M.: Izdatel'stvo inostrannoj literatury. 1963.- $244 \mathrm{~s}$.

5. Bennet K.O Gidrodinamika, teploobmen i massoobmen [Tekst] / Bennet K.O., Majers Dzh. E. M.: Nedra, 1966. - 726 s.

6. Berd R. Yavleniya perenosa [Tekst] / Berd R., St'yuart V., Lajtfut E. M.: Himiya. 1974. 688 s.

7. Pat. 62033 Rossijskaya Federaciya, MPK B 01 D 53/18, B 01 D 46/26. Apparat dlya obrabotki gaza / Shchedrina G.G., Kobelev N.S., Komyagin M.S. i dr.; zayavitel' i patentoobladatel' Kurskij gos. tekhn. un-t. - № 2006140395/22; zavl. 15.11.2006; opubl. 27.03.2007, byul. №9.

8. Shchedrina G.G., Gnezdilova O.A. Morzhavin A.V. $K$ voprosu modelirovaniya teplomassoobmena $v$ energosberegayushchih apparatah osushki vozduha / Evrazijskij soyuz uchenyh (ESU), 2014. - № 8. - S. 100-102.

9. Shchedrina G.G., Gnezdilova O.A. Metody intensifikacii teplomassoobmena $v$ energosberegayushchih apparatah osushki vozduha / Mezhdunarodnyj forum «Krym HI-TECH - 2014»: Sbornik tezisov dokladov. - M, 2015. - S. 269-272.

10. Shchedrina G.G., Gnezdilova O.A. Osobennosti teplomassoobmena v absorbcionnyh ustanovkah / Elektrika, 2015. - № 4. - S. 34-37.

11. Shchedrina G.G., Morzhavin A.V., Shchedrin D.G. Energoeffektivnye sistemy ochistki ventilyacionnyh vybrosov / Materialy VI Mezhdunarodnoj molodezhnoj nauchnoj konferencii «Molodezh' i XXI vek 2016». - 2016, - TOM 3, - S. 353-356. 
12. Shchedrina G.G. Absorbcionnaya osushka vozduha. Modeli i tekhnicheskie resheniya: Monografiya / Kursk: Yugo-Zap. Gos. un-t., 2016. - 116 s.

13. Yezhov, V., Ezhova, T., Semicheva, N., \& Makhova, V. [2017]. Outdoor air conditioning. Journal of Applied Engineering Science, 15(3), 313-318.
14. Ismail, N., Soeparman, S., Widhiyanuriyawan, D., \& Wijayanti, W. [2019]. The influence of pores size and type of aggregate on capillary heat and mass transfer in porous. Journal of Applied Engineering Science, 17(1), 8-17. 